Marcin Ociepa ${ }^{1}$

\title{
THE NATIONAL SPECIALIZATION INDEX IN FOREIGN POLICY OF THE MEMBER STATES OF THE EUROPEAN UNION AS A CONTRIBUTION TO THE EUROPEAN NEIGHBOURHOOD POLICY. AN INTRODUCTION TO THE NOTION
}

Keywords: European Union, Common Foreign and Security Policy, European Neighbourhood Policy, National Specialization Index

\begin{abstract}
The European Neighbourhood Policy as a constituent part of the European Common Foreign and Security Policy is the arena of continuous, inherent as it were, tensions among the ambitions of Member States wanting to play the largest role in the shaping of the European Union's relationships with the surrounding world. A characteristic and obvious quality of this phenomenon is the fact that particular Member States' interests in a given region in the neighbourhood of the European Union increases in proportion to its geographical proximity. This creates naturally the phenomenon of a group of Member States interested or specialized in the region of the Mediterranean Sea, the Black Sea or the Eastern policy. Simultaneously there exists a considerable group of Member States which, because of a considerable distance from a particular region, shows little interest and consequently a frequent lack of understanding of issues related to it. The objective of this article is to capture this phenomenon and to try to systemize it through the notion and methodology of the National Specialization Index.
\end{abstract}

1 Marcin Ociepa, Opole University, Faculty of Social Sciences, marcin.ociepa@ um.opole.pl. 


\section{INTRODUCTION}

The uniqueness of the historical and cultural experiences of direct neighbourhood is the driving force responsible for Europe's developing national specializations in the field of foreign policy which could and should constitute contributions of particular Member States to the European Neighbourhood Policy. While Europe should listen to opinions of Portugal, Spain, France or Italy on matters concerning the Mediterranean Sea basin and North Africa, the same importance should be attached to opinions presented by Poland, the Baltic states or the Scandinavian states and based on their experience of relationships with Russia, Belarus or Ukraine. On the other hand, such historical and cultural relationships are also encumbered with a considerable number of negative experiences. This, in turn, may cause some distortions in the subjective perspective of Member States from the direct neighbourhood, which may be rather difficult to comprehend for Member States situated, metaphorically and literally, further away from a given neighbour area, which makes it difficult, and sometimes even impossible, to work out the European Union's common foreign policy towards a particular state or region.

The objective of this article is a preliminary analysis of the phenomenon and a presentation of the idea of national specializations in a foreign policy on the basis of the newly proposed National Specialization Index, within the context of the European Neighbourhood Policy, and also an introduction to deliberations on the usefulness of this idea for the purposes of the Common Foreign and Security Policy.

\section{THE DIFFERENCES OF PERSPECTIVES}

The European Union's basic tool of exerting influence on its closest neighbourhood is the aforementioned European Neighbourhood Policy (ENP). At present this policy comprises agreements with the following 12 countries being "neighbours" of the European Union: Armenia, Azerbaijan, Egypt, Georgia, Israel, Jordan, Lebanon, Moldova, Morocco, Palestine, Tunisia, and Ukraine. Algeria is still in the process of negotiating its agree- 
ment. Belarus, Libya and Syria remain outside the structures of the ENP, although, from the perspective of the European Union, they could cooperate with EU Member States within the scope of the ENP (Joint Statement of the Ministers of Foreign Affairs...). The official website of the European External Action Service defines the ENP as follows: "Through its European Neighbourhood Policy, the EU works with its Southern and Eastern Neighbours in order to achieve the closest possible political association and the greatest possible degree of economic integration. This objective is being pursued on the basis of joint interest and values - democracy, rule of law, respect for human rights, and social cohesion. The ENP is the key element in the foreign policy of the European Union" (Joint Statement of the Ministers of Foreign Affairs...).

The European Neighbourhood Policy is based both on bilateral agreements entered into between the European Union and the countries invited to participate in the programme and such other multilateral initiatives as the Black Sea Synergy (Joint Statement of the Ministers of Foreign Affairs...), the Union for the Mediterranean (Joint declaration of the Paris summit for the Mediterranean...) and the Eastern Partnership (Joint declaration of the Prague Eastern Partnership Summit...). All these three initiatives came into being or were announced within a very short period of time, i.e. in the years 2007-2008. Thus, it is difficult not to advance the thesis that they had the nature, as it were, of a collective impulse towards the arrangement and intensification of regional cooperation in the immediate vicinity of the European Union.

It should be noted that particular ambitions and priorities of particular Member States were also of considerable importance. The author of the EU's initiative for the Mediterranean was Nicolas Sarkozy, who announced this idea in February 2007 as part of his election programme while running for the office of the French president (Permentier, 2011), and finalized it, already in the capacity of the president of the French Republic during the French presidency in the European Council, at the summit of the heads of 43 states held in Paris in July 2008 (Mediterranean union is launched...). In turn, it is Poland that has always willingly claimed the authorship of the Eastern Partnership: "For Poles, this is something to be proud of," said the then Polish prime minister Donald Tusk at the end of 
the Prague summit on 7 May 2009 (Słojewska, 2009). And Radosław Sikorski, the foreign minister in Donald Tusk's cabinet, declared: "For Poland, this is a successful day in the EU; the day on which the whole EU has adopted a Polish initiative for the first time" (Majewski, 2009).

An important issue which is, however, difficult to settle is to what extent these three multilateral initiatives of the European Union related to the European Neighbourhood Policy have been and continue to be appreciated or at least understood by all Member States and to what extent they have been the result of a compromise based on the principle of the recognition of mutual initiatives. The latter option appears to be more convincing because of the proximity of the dates on which the said initiatives were initiated as well as the following words spoken by the Chancellor of the Federal Republic of Germany Angela Merkel at the Prague summit inaugurating the Eastern Partnership: "(...) our initiating cooperation with the East is as necessary as our cooperation with the Mediterranean" (Majewski, 2009). It should be added that while the Paris summit initiating the Union for the Mediterranean was attended by the leaders of all Member States, what was particularly visible at the Prague summit was the absence of the French president Nicolas Sarkozy, the British prime minister Gordon Brown and the Spanish prime minister Jose Rodriguez Zapatero, who were represented respectively by the French prime minister François Fillon, the British foreign minister David Miliband and the Spanish foreign affairs minister Miguel Angel Moratinos (Joint declaration of the Prague Eastern Partnership Summit...).

At the Lisbon Strategy Forum held in July 2016, Portugal's ambassador to the NATO Luís Almeida Sampaio said that his country's foreign policy was defined by the fact that it neighboured the United States to the west, being separated "only" (the author's quotation marks) by the Atlantic Ocean and the fact that the distance from Lisbon to the capital of Spain, Madrid, was practically the same as the distance to the capital of Morocco, Raba (The Speech...). A similar tone appeared in the statement made in 2008 by the then Member of the European Parliament and the present secretary of state for Euro- 
pean affairs in the Foreign Ministry of Poland Konrad Szymański, who said that we expected the Portuguese or the Spanish people's understanding for Poland's eastern policy in a situation when their knowledge of it is the same as the Poles' knowledge of the internal affairs of Morocco or Algeria².

\section{NATIONAL SPECIALIZATIONS IN THE FOREIGN POLICY OF MEMBER STATES - THE NATIONAL SPECIALIZATION INDEX}

In the author's opinion, such differences in perspectives constitute a major obstacle for the development and implementation of a common foreign policy of the European Union. Therefore, it is worth developing a ranking of national specializations within the scope of the European Neighbourhood Policy or even within the broader scope of the Common Foreign and Security Policy. Supplemented methodologically by the National Specialization Index, such a ranking would be calculated on the basis of very specific criteria described below.

In practice, it would be a ranking of the specializations of Member States dedicated individually to every Member State participating in the European Neighbourhood Policy. The ranking would be based on a point system taking into account the said criteria and would arrange Member States from the one with the highest specialization potential with respect to a third country to the one with the least knowledge of such a country.

Every serious ranking needs to be based on objective criteria. Such criteria need to include both positive criteria, i.e. ones that favour the deeper knowledge of a given region, and negative criteria, i.e. ones that subjectivize the perception of one state by others.

According to the author, the factors favouring objective specialization include the following:

\footnotetext{
2 The author's own interview.
} 
1) A distance between the capital of a Member State and country covered by the ENP (hereinafter: the distance factor). On the basis of the aforementioned statement of Luís Almeida Sampaio, Portugal's ambassador to the NATO, about Portugal's perspective on its neighbourhood with Spain and Morocco, or subsequent policy statements of Polish foreign ministers (Priorities of Polish Foreign Policy 2012-2016...), it can be noticed that this eternal traditional factor, i.e. a distance between countries, continues to play an important role even in the age of globalization. Although states have many possibilities to maintain intensive political and economic relationships with partners from the other end of the world, they always define their foreign policy traditionally with a particular focus on issues related to their immediate neighbourhoods. Undoubtedly, immediate and long-lasting neighbourhood fosters mutual knowledge of neighbours. On the other hand, however, if it is characterized by significant tensions in relationships, which tend to be more frequent in the case of neighbours, it may foster the subjectivization of reception, which also needs to be taken into consideration. This issue is discussed in more detail below.

2) International trade (hereinafter: the commercial factor). It seems that the strength of economic ties is hard to overestimate because it does not depend on relationships between government, which are naturally changeable, but more on the calculations of profits and losses made by individual entrepreneurs considering the possibility of investments in a given country. And what it comprises is the history of previous experiences, the perception of the stability and reliability of the central government and local governments, the forecasts of economic development, as well as interpersonal relationships. In the author's opinion, it is possible to adopt the assumption that the value of trade between two countries fosters their mutual understanding, thus increasing the specialization index of a given Member State.

3) The value of tourist traffic (hereinafter: the tourist factor). Krzysztof Pacławski defines tourism as: “...the entirety of the phenomena of spatial mobility connected with a voluntary and temporary change in the place of stay, the rhythm and environment and the personal contact with the visited (natural, cultural or social) environment" (Przecławski, 
1996). According to this definition, tourist traffic may be understood as that with a recreational, sightseeing, academic or business character. This factor strongly emphasizes the importance of interpersonal relationships for the broadening of people's knowledge and understanding of other nations.

4) Membership in the same international organizations (hereinafter: the membership factor). This factor takes into consideration both the ideological proximity of particular countries and their experiences of cooperation in international fora. The more numerous the planes of empirical political cooperation are, the more complete and accurate the assessment of the partner becomes. While it is difficult to take into consideration a country's membership in the United Nations Organization because of its obviousness, membership in the same smaller organizations based on geographical or ideological factors does matter.

The author identifies the following factors subjectivizing the perception of another country:

1) Bilateral disputes (hereinafter: the dispute factor). Undoubtedly, tensions occurring between neighbouring countries have a significant impact on their mutual perception. The more bilateral, local and contextual they are, the less comprehensible they are for other countries which are not involved in their conflicts. This, in turn, results in the situation in which the severity of statements made by the politicians of one Member State about the policy of a state covered by the ENP has to be treated with some reserve. However, it would be difficult to give this type of disputes or conflicts some weight which would allow the acquisition of a factor constituting a valuable component of the National Specialization Index. Hence, in the author's opinion, it is necessary to resort to the only objective factor, i.e. the period of time which has passed since the latest military conflict between the countries. The longer such a period, the smaller the significance of the factor. It should be concluded that a military conflict is an event important enough to be able to determine not only a state's international policy but also the public feeling for many generations to come.

2) Religious differences (hereinafter: the religious factor). Religious issues exert continuous impact on international policy. And 
although it is difficult to determine to what extent religion is a cause of, or a pretext for, many contemporary conflicts, it is beyond doubt that religious differences have a subjectivizing influence on the foreign policy of states. Quite another matter is to what extent it is at all possible to capture the importance of this factor methodologically. Hence the proposal to take into consideration the most obvious difference which occurs when the majority of the citizens of a Member State identify themselves with a religion different from that followed by the majority of a state covered by the ENP. An important proviso is that a different value should be assigned to differences occurring between denominations within one religion, e.g. Catholicism and the Orthodox Church within Christianity, and a different value to differences between religions, e.g. Christianity and Islam.

\section{POLAND - UKRAINE. A CASE STUDY EXEMPLIFYING THE APPLICATION OF THE FACTORS OF DISTANCE, COMMERCE AND MEMBERSHIP}

\section{1) The distance factor}

The application of the National Specialization Index to the example comprising the Republic of Poland, a Member State of the European Union, and Ukraine, a state covered by the European Neighbourhood Policy with respect to the distance factor is presented below.

The base value of the factor is $1000 \mathrm{~km}$. A distance above $1000 \mathrm{~km}$ is considered insignificant, while a distance below $1000 \mathrm{~km}$ is regarded as a factor favourable for national specialization. The distance between Warsaw and Kiev is $690 \mathrm{~km}$.

In itself, the value of the distance may be perceived only subjectively as small or, just the opposite, as considerable. It acquires a methodological value only after applying a comparison with other states within the scope of developing a national specialization ranking mentioned above. Then we acquire an objective distance factor which obviously allows the arrangement of the Member States from the one located the closest to the one located the farthest from a state covered by the ENP. 
Table 1. The distances between the capitals of the EU Member States and Kiev, Ukraine

\begin{tabular}{|c|c|c|c|}
\hline$\#$ & Member State & Capital & Distance \\
\hline 1. & Lithuania & Vilnus & $590 \mathrm{~km}$ \\
\hline 2. & Poland & Warsaw & $690 \mathrm{~km}$ \\
\hline 3. & Romania & Bucharest & $748 \mathrm{~km}$ \\
\hline 4. & Latvia & Riga & $837 \mathrm{~km}$ \\
\hline 5. & Hungary & Budapest & $900 \mathrm{~km}$ \\
\hline 6. & Slovakia & Bratislava & $1005 \mathrm{~km}$ \\
\hline 7. & Bulgaria & Sofia & $1023 \mathrm{~km}$ \\
\hline 8. & Austria & Vienna & $1055 \mathrm{~km}$ \\
\hline 9. & Estonia & Tallinn & $1065 \mathrm{~km}$ \\
\hline 10. & Finland & Helsinki & $1137 \mathrm{~km}$ \\
\hline 11. & Czech Rep. & Prague & $1143 \mathrm{~km}$ \\
\hline 12. & Croatia & Zagreb & $1195 \mathrm{~km}$ \\
\hline 13. & Germany & Berlin & $1206 \mathrm{~km}$ \\
\hline 14. & Sweden & Stockholm & $1266 \mathrm{~km}$ \\
\hline 15. & Slovenia & Ljubljana & $1281 \mathrm{~km}$ \\
\hline 16. & Denmark & Copenhagen & $1329 \mathrm{~km}$ \\
\hline 17. & Greece & Athens & $1488 \mathrm{~km}$ \\
\hline 18. & Italy & Rome & $1677 \mathrm{~km}$ \\
\hline 19. & Cyprus & Nicosia & $1715 \mathrm{~km}$ \\
\hline 20. & Luxemburg & Luxemburg & $1734 \mathrm{~km}$ \\
\hline 21. & Netherlands & Amsterdam & $1782 \mathrm{~km}$ \\
\hline 22. & Belgium & Brussels & $1838 \mathrm{~km}$ \\
\hline 23. & France & Paris & $2026 \mathrm{~km}$ \\
\hline 24. & Malta & Valletta & $2068 \mathrm{~km}$ \\
\hline 25. & United Kingdom & London & $2136 \mathrm{~km}$ \\
\hline 26. & Ireland & Dublin & $2519 \mathrm{~km}$ \\
\hline 27. & Spain & Madrid & $2866 \mathrm{~km}$ \\
\hline 28. & Portugal & Lisbon & $3356 \mathrm{~km}$ \\
\hline
\end{tabular}

Source: the author's own work. 
The table above shows that the states located the closest to Kiev include Lithuania, Poland, Romania, Latvia and Hungary. The five capitals located the farthest from Kiev are the capitals of Portugal, Spain, Ireland, the United Kingdom and Malta. The distinction of the five closest and the five most distant states will be discussed in the subsequent part of this article devoted to the potential for implementing the National Specialization Index in various institutions of the European Union.

2) The commercial factor

From the Ukrainian point of view, Poland is one of Ukraine's five largest commercial partners, with respect to both export and import:

Table 2. Ukraine's international trade in 2015 major commercial partners

\begin{tabular}{|c|l|c|l|c|}
\hline$\#$ & Importers & $\begin{array}{c}\text { Value of goods } \\
\text { imported } \\
\text { from Ukraine }\end{array}$ & Exporters & $\begin{array}{c}\text { Value of goods } \\
\text { exported } \\
\text { to Ukraine }\end{array}$ \\
\hline 1. & Russia & $12.7 \%$ & Russia & $20 \%$ \\
\hline 2. & Turkey & $7.3 \%$ & Germany & $10.4 \%$ \\
\hline 3. & China & $6.3 \%$ & China & $10.1 \%$ \\
\hline 4. & Egypt & $5.5 \%$ & Belarus & $6.5 \%$ \\
\hline 5. & $\begin{array}{l}\text { Poland } \\
\text { (and Italy } \\
\text { equally) }\end{array}$ & $5.2 \%$ & Poland & $6.2 \%$ \\
\hline
\end{tabular}

Source: the author's own work on the basis of the data of the Ukrainian National Statistical Office.

Also in this case, the data presented above constitute input in the process of comparing various Member States of the European Union. The table above indicates, however, that the commercial factor increases the Ukrainian specialization index for such countries as Poland, Germany, and Italy.

3) The membership factor

From among numerous international organizations to which Ukraine and/or Poland belong, the author has subjectively selected the following: 
Table 3. Membership in international organizations

\begin{tabular}{|l|c|c|c|}
\hline \multicolumn{1}{|c|}{ Name of organization } & $\begin{array}{c}\text { Membership } \\
\text { of Ukraine }\end{array}$ & $\begin{array}{c}\text { Membership } \\
\text { of Poland }\end{array}$ & $\begin{array}{c}\text { Concur- } \\
\text { rence }\end{array}$ \\
\hline United Nations Organization & YES & YES & 1 \\
\hline European Union & NO & YES & 0 \\
\hline Council of Europe & YES & YES & 1 \\
\hline $\begin{array}{l}\text { North Atlantic Treaty Organi- } \\
\text { zation }\end{array}$ & NO & YES & 0 \\
\hline $\begin{array}{l}\text { Organization for Security } \\
\text { and Cooperation in Europe }\end{array}$ & YES & YES & 1 \\
\hline World Trade Organization & YES & YES & 1 \\
\hline World Bank & YES & YES & 1 \\
\hline International Monetary Fund & YES & YES & 1 \\
\hline
\end{tabular}

Source: the author's own work.

The table above includes a conclusion concerning membership in the form of an either/or specification which could be used to develop a more measurable point system comprising all other Member States.

\section{CONCLUSIONS: POTENTIAL FOR THE IMPLEMENTATION OF THE NATIONAL SPECIALIZATION INDEX IN THE EUROPEAN UNION}

What applications could a complete and multi-factor national specialization ranking have? The very development of such an index based on selected variables appears to be of little cognitive interest. However, its implementation potential cannot be ignored. In discussions of particular issues related to the European Neighbourhood Policy, the European Union's decision-making authorities could refer to such a ranking by requesting a representative of a particular state with a high place in a ranking to prepare an introductory report to a discussion and at the same time requesting a representative of a states holding a low position in a ranking 
to prepare a supplementary report presenting a point of view of states being geographically and politically the most distant from a problem at hand.

Another systemic change which could be implemented on the basis of the aforementioned index and rankings is a key for the nationality-based selection of directors of the EU representative missions in third countries. In this case, it could be also assumed that the head of a representative mission or the EU ambassador has to come from one of the top five Member States in the specialization ranking and their deputy - from one of the bottom five ones.

The use of this system in which political fervour resulting from immediate neighbourhood is cooled down by the distance of a more detached country may result, firstly, in the higher probability of the Member States' making a quick decision within the EU's external policy and, secondly, in a gradual increase in the interest of all Member States in the whole neighbourhood of the European Union as opposed to interest in the nearest vicinity, which, in turn, should lead to higher sensitivity, solidarity and, first of all, faster joint reactions of the whole community to challenges in the field of the common foreign and security policy.

It should be also noted that this model may constitute an important factor discouraging third countries in the direct vicinity of the European Union (e.g. Russia) from ignoring their neighbours belonging to the European Union (e.g. Poland) in their dialogues with the European Commission or the larger Members States being nevertheless more distant from the area of particular disputes (e.g. France).

\section{BIBLIOGRAPHY:}

Joint declaration of the Paris summit for the Mediterranean. Downloaded from: http:// www.consilium.europa.eu/uedocs/cms_data/docs/pressdata/en/er/101847.pdf . Joint declaration of the Prague Eastern Partnership Summit. Downloaded from: http:// www.consilium.europa.eu/uedocs/cms_data/docs/pressdata/en/er/107589.pdf. 
Joint Statement of the Ministers of Foreign Affairs of the countries of the European Union and of the wider Black Sea area. Downloaded from: http://eeas.europa.eu/archives/ docs/blacksea/doc/joint_statement_blacksea_en.pdf .

Majewski, P. (2009). Szczyt z inicjatywy Polski. Downloaded from: http://www.rp.pl/ artykul/301990-Szczyt-z-inicjatywy-Polski.html\#ap-1.

Mediterranean union is launched. Downloaded from: http://news.bbc.co.uk/2/hi/ europe/7504214.stm.

Permentier, F. (2011). Powrót południowego sąsiedztwa. Nowa Europa Wschodnia, 3-4, pp. $164-165$.

Priorities of Polish Foreign Policy 2012-2016. Downloaded from: http://msz.gov.pl/pl/ polityka_zagraniczna/priorytety_polityki_zagr_2012_2016/expose2/ .

Przecławski, K. (1996). Człowiek a turystyka - zarys socjologii turystyki. Kraków: Albis.

Słojewska, A. (2009), Unia bliżej wschodu Europy. Rzeczpospolita, 08.05.

The speech given by ambassador Luís Almeida Sampaio at the Lisbon Strategy Forum 2016 organized by the Embassy of the Republic of Poland in Lisbon, 26 VII 2016. 